\title{
Editors of APA Journals
}

\author{
2009 Address List
}

To assist authors of manuscripts submitted to APA journals, APA journal editors' addresses are listed below. The Internet addresses provide links to journal-specific Web pages. The "Authors Corner" (www .apa.org/journals/authors) contains general resources for authors, and the "Instructions to Authors" section of these pages contains any special journal requirements. Style and formatting requirements can be found in the Publication Manual of the American Psychological Association, 6th ed. (see also www.apastyle.apa.org). All journals receive submissions electronically through the Journals Back Office portal. The following list may be reproduced without permission from APA.

American Psychologist

www.apa.org/journals/amp

Norman B. Anderson, PhD

(2003-)

American Psychological Association

750 First Street, NE

Washington, DC 20002-4242

Behavioral Neuroscience

www.apa.org/journals/bne

Mark S. Blumberg, PhD

(2009-2014)

Department of Psychology

E11 Seashore Hall

University of Iowa

Iowa City, IA 52242

Developmental Psychology

www.apa.org/journals/dev

Cynthia García Coll, PhD

(2005-2010)

Brown University

Center for the Study of Human Development

Box 1831

133 Waterman Street

Providence, RI 02912

Emotion

www.apa.org/journals/emo

Elizabeth A. Phelps, PhD

(2007-2012)

Department of Psychology

New York University

6 Washington Place, Room 863

New York, NY 10003
Experimental and Clinical

Psychopharmacology

www.apa.org/journals/pha

Nancy K. Mello, PhD

(2006-2011)

Experimental and Clinical

Psychopharmacology

McLean Hospital

Massachusetts General Hospital

Harvard Medical School

115 Mill Street

Belmont, MA 02478-9106

\section{Health Psychology}

www.apa.org/journals/hea

Robert M. Kaplan, $\mathrm{PhD}$

(2006-2010)

Department of Health Sciences

UCLA School of Public Health

650 Charles E. Young Drive

P.O. Box 951772, Room 31-293CHS

Los Angeles, CA 90025-1772

Journal of Abnormal Psychology

www.apa.org/journals/abn

David Watson, PhD

(2006-2011)

Journal of Abnormal Psychology

Department of Psychology

University of Iowa

Iowa City, IA 52242-1407

Journal of Applied Psychology

www.apa.org/journals/apl

Steve W. J. Kozlowski, PhD

(2009-2014)

Department of Psychology

309 Psychology Building

Michigan State University

East Lansing, MI 48824-1116

Journal of Comparative Psychology

www.apa.org/journals/com

Gordon M. Burghardt, $\mathrm{PhD}$

(2006-2011)

Journal of Comparative Psychology

Department of Psychology

University of Tennessee

Knoxville, TN 37996

Journal of Consulting and Clinical

Psychology

www.apa.org/journals/ccp

Annette M. La Greca, PhD

(2005-2010)

Department of Psychology

P.O. Box 249229

University of Miami

Coral Gables, FL 33124-0751
Journal of Counseling Psychology

www.apa.org/journals/cou

Brent S. Mallinckrodt, PhD

(2006-2011)

Journal of Counseling Psychology

Department of Psychology

University of Tennessee

1404 Circle Drive, Room 312

Knoxville, TN 37996-0900

Journal of Educational Psychology

www.apa.org/journals/edu

Art Graesser, $\mathrm{PhD}$

(2009-2014)

202 Psychology Building

Department of Psychology

University of Memphis

Memphis, TN 38152-3230

Journal of Experimental Psychology:

Animal Behavior Processes

www.apa.org/journals/xan

Anthony Dickson, PhD, Incoming Editor (2010-2015)

Department of Experimental Psychology

University of Cambridge

Downing Street

Cambridge CB2 3EB

United Kingdom

Nicholas J. Mackintosh, PhD

(2004-2009)

Department of Psychology

University of Cambridge

Downing Street

Cambridge CB2 3EB

United Kingdom

Journal of Experimental Psychology: Applied

www.apa.org/journals/xap

Wendy A. Rogers, PhD

(2008-2013)

School of Psychology

Georgia Institute of Technology

Mail Code 0170

654 Cherry Street

Atlanta, GA 30332-0170

Journal of Experimental Psychology: General

www.apa.org/journals/xge

Fernanda Ferreira, $\mathrm{PhD}$

(2008-2013)

School of Philosophy, Psychology, and

Language Sciences

University of Edinburgh

7 George Square

Edinburgh EH8 9JZ, Scotland

United Kingdom 
Journal of Experimental Psychology:

Human Perception and Performance www.apa.org/journals/xhp

Glyn W. Humphreys, PhD

(2006-2011)

Journal of Experimental Psychology: Human

Perception and Performance

Behavioural Brain Sciences Centre

School of Psychology

University of Birmingham, Edgbaston

Birmingham B15 2TT

United Kingdom

Journal of Experimental Psychology:

Learning, Memory, and Cognition

www.apa.org/journals/xlm

Randi C. Martin, $\mathrm{PhD}$

(2007-2012)

Department of Psychology, MS-25

Rice University

P.O. Box 1892

Houston, TX 77251

Journal of Family Psychology

www.apa.org/journals/fam

Nadine Kaslow, PhD, Incoming Editor

(2010-2015)

Emory University School of Medicine

Department of Psychiatry and Behavioral Sciences

Grady Health System Room 13D018

80 Jesse Hill Jr. Drive NE

Atlanta, GA 30303

Anne E. Kazak, PhD

(2004-2009)

The Children's Hospital of Philadelphia

34th and Civic Center Boulevard

Room 1486 CHOP North

Philadelphia, PA 19104-4399

Journal of Personality and Social

Psychology

www.apa.org/journals/psp

JPSP: Attitudes and Social Cognition

Charles M. Judd, PhD

(2006-2011)

Attn: JPSP: ASC

Department of Psychology

University of Colorado

UCB 345

Boulder, CO 80309-0345

JPSP: Interpersonal Relations and Group Processes

Jeffry A. Simpson, $\mathrm{PhD}$

(2009-2014)

Department of Psychology

University of Minnesota

75 East River Road

N394 Elliott Hall

Minneapolis, MN 55455-0344
JPSP: Personality Processes and Individual Differences

Laura A. King, PhD, Incoming Editor

(2010-2015)

Department of Psychological Sciences

University of Missouri

McAlester Hall

Columbia, MO 65211

Charles S. Carver, PhD

(2004-2009)

Attn: JPSP: PPID

Department of Psychology

University of Miami

P.O. Box 248185

Coral Gables, FL 33124-2070

Neuropsychology

www.apa.org/journals/neu

Stephen M. Rao, PhD

(2008-2013)

Neurological Institute, Cleveland Clinic

9500 Euclid Avenue, U10

Cleveland, $\mathrm{OH} 44195$

Professional Psychology: Research and Practice

www.apa.org/journals/pro

Michael C. Roberts, PhD

(2007-2012)

Department of Applied Behavioral Science

Clinical Child Psychology Program

University of Kansas

1000 Sunnyside Avenue

Lawrence, KS 66045-0001

Psychological Assessment

www.apa.org/journals/pas

Cecil R. Reynolds, PhD, Incoming Editor

(2010-2015)

Texas A\&M University

Department of Educational Psychology

704 Harrington Education Center

College Station, TX 77843-4225

Milton E. Strauss, PhD

(2004-2009)

Department of Psychology

Case Western University

Cleveland, $\mathrm{OH}$ 44106-7123

Psychological Bulletin

www.apa.org/journals/bul

Stephen P. Hinshaw, PhD

(2009-2014)

Department of Psychology

University of California

Tolman Hall \#1650

Berkeley, CA 94720

Psychological Methods

www.apa.org/journals/met

Scott Maxwell, PhD

(2008-2013)

Psychological Methods

Department of Psychology

118 Haggar Hall

University of Notre Dame

Notre Dame, IN 46556-5636
Psychological Review

www.apa.org/journals/rev

Keith Rayner, PhD

(2004-2010)

Department of Psychology

Tobin Hall

University of Massachusetts

Amherst, MA 01003

Psychology of Addictive Behaviors

www.apa.org/journals/adb

Stephen A. Maisto, PhD, ABPP

(2009-2014)

Department of Psychology

Center for Health and Behavior

Syracuse University

430 Huntington Hall

Syracuse, NY 13244

Psychology and Aging

www.apa.org/journals/pag

Fredda Blanchard-Fields, PhD

(2008-2013)

School of Psychology

Georgia Institute of Technology

654 Cherry Street

Atlanta, GA 30332-0170

Psychology, Public Policy, and Law www.apa.org/journals/law

Ronald Roesch, $\mathrm{PhD}$

(2008-2012)

Mental Health, Law, and Policy Institute

Simon Fraser University

8888 University Drive

Burnaby, British Columbia V5A 1S6

Canada

Rehabilitation Psychology

www.apa.org/journals/rep

Timothy R. Elliott, PhD

(2006-2011)

Rehabilitation Psychology

Department of Educational Psychology

Texas A\&M University

College Station, TX 77843-4225

\section{Secondary Journals}

Clinician's Research Digest

Thomas E. Joiner Jr., PhD

(2007-2012)

Department of Psychology

Florida State University

One University Way

Tallahassee, FL 32306-1270

PsycCRITIQUES-Contemporary

Psychology: APA Review of Books

Danny Wedding, PhD

(2005-2010)

Missouri Institute of Mental Health

School of Medicine

5400 Arsenal Street

St. Louis, MO 63139 